\title{
レオメトリー特集号に添えて Foreword to Special Issue for Rheometry
}

\author{
酒井 啓司* \\ Keiji Sakai \\ 高橋 勉 $* *$ \\ Tsutomu Takahashi
}

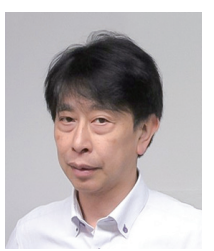

K. Sakai

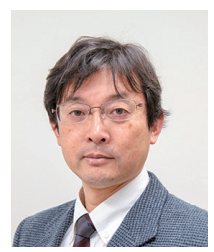

T. Takahashi

\section{特集号企画の意図}

物性の研究と計測技術開発は表裏一体のものです，しかし数ある計測技術の体系の中で,「流れるもの」の物理を記述する レオロジーの測定技術の歴史は, 実は驚くほど浅いのです（みなさん，キャノンフェンスケやウーベローデの論文の年次をご 存知でしょうか!? ${ }^{1)}$ 。ささらにその原器はいまでもガラス製の細管であり, また標準試料は $20^{\circ} \mathrm{C}$ の蒸留水と, 状況はいまだに ひと世代ほど昔の感があります。世界の物理量がすべて量子標準によって測られようとしている現代に抏いて，レオロジー計 測がいつまでもこのままでいいわけがありません，幸い近年になり，電場や磁場，光や画像計測の技術を駆使する新しいレオ ロジーの探求技術の開発がわが国でも活発に進められ，例えばミクロやナノの世界，生きている細胞の中の流体物性，あるい はこれまで手を出すことのできなかった極限環境へのレオロジープローブの開発が始まっています，今回はこのような新規の， そして斬新なアイデアに基づく「レオロジー計測」への挑戦を皆様に紹介すべく，「レオメトリー」特集号を企画いたしまし た.

\section{レオメトリーとは?}

私たちの生活を支える重要な物質であるソフトマターは, より便利に，より快適に，より安定的に使用できるようさまざま な分野で日々開発が続けられています。ソフトマターや複雑流体の分野では物質のミクロ的・マクロ的構造のわずかな違いが 力学的特性に大きく影響を及ぼします。素材を開発する立場においては, 材料の配合や添加剤, 粒子形状・サイズなどの微細 な条件を調整して力学的特性を変化させ, 高機能化や安定性向上, 新たな付加価値などを生み出しますが, これとは逆に力学 的特性の測定から物質内部で起こっている未知のミクロ的・マクロ的変化を解き明かしていくのがレオメトリーになります. 力と変形の関倸という平均的な測定結果をもとにミク口的な構造変化を類推する必要がありますので, 現象に対する的確な判 断を下すには多くの経験と知識が必要になります，少しでも正確な検討を行うためにはできる限り多くの，そして正確な情報 が必要です。このため, 従来よりも高精度な計測技術, 伸張粘度や第 2 法線応力差などの測定が困難と考えられている物性の 測定技術，そしてミクロ的構造を直接感知できる電場，磁場，光物性測定技術などがレオロジー計測に取り入れられてきまし た。この特集号では最新の技術や新しい視点を導入したソフトマター開発を支える計測技術，レオメトリーの新たな潮流がご 紹介できたと思います，寄稿くださいました皆様に心より感謝申し上げます。この特集号を機にレオメトリー技術のさらなる 発展を願いますとともに，これらの技術を活用したレオロジーの新しい展開が進みますことを期待し，巻頭言とさせていただ きます。

1) 例えば, M. R. Cannon and M. R. Fenske, “Viscosity Measurement”, Ind. Eng. Chem. Analytical Edition, 10, 297-301 (1938).

* 東京大学生産技術研究所

** 長岡技術科学大学 機械創造工学専攻 